Jurnal Akuntansi Indonesia, Vol. 10 No. 1 Januari 2021, Hal. 41 - 59

\title{
Kepatuhan Wajib Pajak UMKM Di Masa Pandemi Covid-19
}

\author{
Listiyowati \\ lin Indarti \\ Fitri Wijayanti \\ Freddy Aldo Setiawan \\ STIE Widya Manggala \\ listiyowati@widyamanggala.ac.id \\ iinindarti91@ymail.com \\ fitriwijayanti04@gmail.com \\ freddyaldosetiawan@gmail.com
}

\begin{abstract}
ABSTRAK
UMKM merupakan bentuk usaha kerakyatan untuk menopang perekonomian negara dimana di dalam masa pandemi Covid-19, UMKM merupakan usaha yang paling terdampak. Masalah klasik yang sering muncul adalah rendahnya tingkat pembayaran pajak oleh UMKM. Sehingga dengan PP No. 23 tahun 2018 yang berlaku 1 Juli 2018 dimana pemerintah menurunkan tarif pajak final bagi UMKM yang awalnya 1\% menjadi 0.5\% diharapkan mampu meningkatkan kesadaran WP untuk patuh membayar pajak pada masa pandemi covid-19. Dalam penelitian ini faktor-faktor yang diambil adalah Sosialisasi Perpajakan, Pelayanan Fiskus, dan Pelaksanaan Self Assessment System. Penelitian ini dilakukan pada Wajib Pajak UMKM di kota Semarang, Tujuan dari penelitian ini adalah untuk mengetahui seberapa besar tingkat pengaruh Sosialisasi Perpajakan, Pelayanan Fiskus, dan Pelaksanaan Self Assessment System terhadap kepatuhan wajib pajak pada saat pandemi Covid-19. Populasinya adalah Wajib Pajak UMKM di Kota Semarang berjumlah 2.129 WP. Teknik pengambilan sampling menggunakan simple random sampling dengan rumus slovin didapatkan sampel berjumlah 95 WP. Alat analisis menggunakan regresi linier berganda dan uji asumsi klasik digunakan untuk menilai tingkat penyimpangan data. Hasil penelitian menunjukkan bahwa Sosialisasi Perpajakan dan Pelayanan Pajak tidak berpengaruh terhadap kepatuhan WP, sedangkan Pelaksanaan Self Assessment System berpengaruh positif signifikan terhadap kepatuhan wajib pajak pada saat pandemi Covid-19. Uji Koefisien Determinasi menyebutkan bahwa ketiga variabel mampu memberikan pengaruh terhadap kepatuhan wajib pajak sebesar 21.9\%, sedangkan sisanya sebesar $79.1 \%$ dipengaruhi variabel lain diluar penelitian.
\end{abstract}

Kata Kunci: UMKM, Covid-19,Kepatuhan Wajib Pajak, Sosialisasi Perpajakan, Pelayanan Pajak, Pelaksanaan Self Assessment System, Covid-19 


\section{ABSTRACT}

MSMEs are a form of community effort to support the country's economy, where during the Covid-19's pandemic, MSMEs were the most affected businesses.The classic problem that often arises is the low level of tax payments by MSMEs. So that with PP. 23 of 2018 which took effect on $1 \mathrm{July} 2018$, where the government reduced the final tax rate for MSMEs from $1 \%$ to $0.5 \%$, which is expected to increase the awareness of taxpayers to comply with paying taxes inthe pandemic of covid-19. In this study, the factors taken were the Socialization of Taxation, Fiscus Service, and Implementation of the Self Assessment System. This research was conducted at MSME's taxpayers in the Semarang city. The purpose of this study was to determine how much influence the level of taxation socialization, fiscal services, and implementation of the self-assessment system on taxpayer compliance during the Covid-19 pandemic. The population is 2,129 taxpayers of MSME in Semarang City. The sampling technique used simple random sampling with the Slovin formula obtained a sample of 95 WP. The analysis tool uses multiple linear regression and classical assumption test is used to assess the degree of deviation of the data. The results showed that the socialization of taxation and tax services had no effect on taxpayer compliance, while the implementation of the Self Assessment System had a significant positive effect on taxpayer compliance during the Covid-19 pandemic. The determination coefficient test states that the three variables are able to have an effect on taxpayer compliance by $21.9 \%$, while the remaining $79.1 \%$ is influenced by other variables outside the research.

Keywords : MSME's, Covid-19, Taxpayer Compliance, Tax Socialization, Fiscus Service,Implementation of Self Assessment System

\section{PENDAHULUAN}

\section{Latar Belakang}

Pada saat ini seluruh negara dibelahan dunia manapun tengah dilanda wabah Novel Corona Virus Disease 19 (Covid-19). Wabah yang telah melanda seluruh belahan negara ini disebut dengan pandemi. Pandemi ini dinyatakan belum diketahui kapan akan berakhir. Dengan adanya pandemi ini seluruh negara dilanda berbagai efek atau dampak yang mempengaruhi sistem ketatanegaraan. Secara makro, dampak dari pandemi ini akan mengganggu jalannya roda pemerintahan. Seperti yang kita ketahui pandemi ini mempengaruhi perekonomian secara global, tidak hanya di Indonesia saja. Dalam mengatasi hal ini pemerintah telah sigap untuk mengeluarkan berbagai kebijakan. Menurut data yang berasal dari Kementerian Keuangan, pertumbuhan ekonomi Indonesia tahun 2020 diperkirakan akan menjadi lebih lambat jika dibandingkan dengan tahun sebelumnya. Penurunan tingkat pertumbuhan ekonomi tersebut sangat terasa pada triwulan II dan III. Selain itu, social distancing sebagai sebuah upaya untuk memutus rantai menyebarnya covid-19 telah membuat penurunan pada aktivitas ekonomi dan produktivitas pelaku usaha yang menimbulkan penurunan pada penerimaan pajak. (www.pajak.go.id)

Pajak merupakan salah satu bentuk pendapatan negara yang menyumbang persentase terbesar dibandingkan dengan sektor pendapatan lain seperti minyak dan gas (migas) serta non-migas. Keberhasilan suatu negara dalam mengumpulkan pajak dari warga negaranya dipastikan akan bermanfaat bagi stabilitas ekonomi negara yang bersangkutan (Farouq, 2018: 1). Sumber pendapatan negara dari pajak telah menjadi 
unsur utama dalam menunjang kegiatan perekonomian, menggerakkan roda pemerintahan dan penyediaan fasilitas umum bagi masyarakat. Bahkan pada beberapa Tahun belakangan ini, pajak memenuhi kurang lebih 70 persen penerimaan dalam Anggaran Pendapatan dan Belanja Negara (APBN). Hal ini menunjukkan peranan pajak dalam mewujudkaLIn stabilitas roda kehidupan negeri ini harus semakin ditingkatkan, mengingat semakin tingginya tuntutan kebutuhan dan semakin kompleksnya tantangan zaman modern (Farouq, 2018: 127).

Menurut Simanjuntak, dkk, (2012) Salah satu ukuran keberhasilan suatu kebijakan perpajakan dapat dilihat dari kecenderungan peningkatan hasil penerimaan negara dari sektor perpajakan dalam satu periode melalui upaya ekstensifikasi yaitu upaya meningkatkan penerimaan pajak dengan cara menambah jumlah Wajib Pajak (WP) yang belum terdaftar atau menambah jumlah jenis pajak yang baru. Sedangkan yang dimaksud upaya intensifikasi adalah meningkatkan penerimaan pajak dari WP yang sudah terdaftar. Kedua metode tersebut cara efisien untuk meningkatkan kepatuhan pajak masyarakat, perbaikan pelayanan pajak, dan lain-lain. Farouq (2018:3) berpendapat Kepatuhan WP merupakan salah satu kunci keberhasilan pemerintah dalam menghimpun penerimaan pajak, bukan sekedar menonjolkan aspek pemungutan pajak yang bersifat "memaksa", tetapi juga harus diikuti dengan serangkaian regulasi, prosedur dan pelayanan administrasi yang jelas dan berkelas. Menurut Miladia (2010) dalam Maharani (2015) agar target pajak tercapai, diperlukan kesadaran dan kepatuhan WP untuk memenuhi kewajiban pajak sesuai dengan ketentuan yang berlaku. Hal itu merupakan suatu faktor yang penting bagi peningkatan penerimaan pajak, sehingga perlu secara rutin dikaji mengenai faktor-faktor yang mempengaruhi kepatuhan WP.

Usaha Kecil dan Menengah (UKM) merupakan salah satu bagian terpenting dalam perekonomian kerakyatan yang terkena dampak besar adanya penyebaran pandemi Covid 19 ini. Diantaranya penurunan permintaan, pemasaran produk, akses bahan baku dan masih rendahnya SDM. Sehingga hal ini berdampak terhadap turunnya tingkat penjualan bahkan banyak UMKM yang gulung tikar. Ketika hal ini terjadi, maka secara langsung akan membuat UMKM akan menurunkan tingkat biaya yang menjadi beban perusahaan. Salah satunya adalah beban pajak. Sehingga hal ini mendorong pemerintah untuk mengeluarkan kebijakan stimulus untuk mendongkrak UMKM untuk tetap going concern melalui penurunan nilai tarif pajak UMKM. Sehingga tingkat kepatuhan UMKM untuk membayar pajak tetap terjaga. di suatu wilayah maupun suatu Negara. Usaha kecil dan menengah sangat berperan dalam perekonomian Indonesia, sebagai contoh usaha kecil dan menengah sangat berperan penting pada saat terjadinya krisis moneter tahun 1998 dan dipandang sebagai suatu penyelamat dalam proses perekonomian Indonesia, mendorong laju pertumbuhan ekonomi maupun penyerapan tenaga kerja, (Maharani, 2015). Pada Kantor Pelayanan Pajak (KPP) Pratama Semarang Tengah Dua menggelar Kegiatan Program Business Development Service (BDS) untuk Usaha Mikro Kecil dan Menengah (UMKM) yang bertujuan agar usaha yang dikelola WP dapat berkembang pesat khususnya melalui pemasaran online. Pada kegiatan tersebut, diberikan edukasi pajak mengenai turunnya tarif pajak UMKM terbaru dari 1 persen menjadi 0,5 persen sesuai dengan Peraturan Pemerintah Nomor 23 Tahun 2018 yang berlaku mulai 1 Juli 2018. Dengan turunnya tarif UMKM ini, diharapkan adanya kepatuhan WP dalam membayar pajak untuk negara (www.pajak.go.id).

Kepatuhan Wajib Pajak Umkm Di Masa Pandemi Covid-19 Listiyowati, lin Indarti, Fitri Wijayanti \& Freddy Aldo Setiawan STIE Widya Manggala 
Sebenarnya permasalahan rendahnya tingkat kepatuhan pajak (tax compliance) oleh WP dalam membayar pajak merupakan masalah klasik yang dihadapi hampir semua negara yang menerapkan sistem perpajakan, sehingga berimplikasi pada rendah ratio penerimaan pajak. Berbagai penelitian telah dilakukan dan kesimpulannya adalah masalah kepatuhan kepatuhan dapat dilihat dari segi keuangan publik (public finance), penegakkan hukum (law enforcement), struktur organisasi (organizational structure), tenaga kerja (employees), etika (code of conduct), atau gabungan dari semua segi tersebut, (Farouq, 2018: 2-3). Kebijakan pemerintah memberikan insentif kepada pelaku UMKM dengan menurunkan tarif Pajak Penghasilan (PPh) Final menjadi 0,5 persen dari sebelumnya 1 persen. Dalam penurunan tarif PPh Final UMKM yang tertera dalam Peraturan Pemerintah (PP) Nomor 23 Tahun 2018 tentang PPh atas Penghasilan dari Usaha yang Diterima atau Diperoleh WP yang Memiliki Peredaran Bruto tertentu sebagaimana aturan itu merupakan pengganti PP Nomor 46 Tahun 2013, Pemerintah berupaya untuk lebih meningkatkan kepatuhan WP. Oleh karena itu, DJP akan terus melakukan berbagai pendekatan dengan para pelaku usaha dengan mencoba membantu mengembangkan bisnisnya. Kemenkeu mengakui saat ini kontribusi pajak UMKM masih sangat kecil kepada total penerimaan negara. Namun, menurutnya potensi penerimaan pajak dari sektor UMKM masih sangat besar mengingat pelaku UMKM sangat banyak dan tersebar di seluruh Indonesia (www.nasional.kontan.co.id).

Dinas koperasi dan usaha mikro kecil dan menengah (UMKM) Kota Semarang setiap tahunnya mencatat pertumbuhan sekitar 2000 UMKM, hal ini mencerminkan bahwa peningkatan UMKM di Kota Semarang dapat membantu perekonomian di Ibu Kota Jawa Tengah. Peningkatan UMKM di Kota Semarang ini terlihat dari kuantitas dan kualitas nya terbukti adanya peningkatan omzet. Dinas koperasi dan UMKM pun ikut melakukan pendampingan dalam setiap berkembangnya UMKM tersebut baik dari segi penataan administrasinya hingga manajemen pemasaran. Dengan adanya peningkatan UMKM setiap tahunnya, banyak kemajuan positif dalam pembangunan perekonomian, terutama dalam penerimaan pajak dari sektor usaha mikro, kecil, dan menengah (UMKM). Dari tahun ke tahun, UMKM di Jawa Tengah banyak mengalami peningkatan, terutama di Kota Semarang, di kutip dari (www.jateng.antaranews.com).

Sehingga untuk mencapai hal itu, DJP akan berupaya untuk mengoptimalkan sosialisasi kepada masyarakat dengan meningkatkan pelayanan fiskus kepada WP. Selain bisa meningkatkan kepatuhan, skema kebijakan tersebut diharapkan dalam jangka menengah panjang bisa ikut mendorong perekonomian karena penurunan tarif pajak bisa dimanfaatkan UMKM untuk menambah modal usahanya serta dapat mendorong kepada UMKM agar usahanya bisa lebih berkembang lagi (www.republika.co.id).

Salah satu faktor yang mempengaruhi kepatuhan Wajib Pajak yaitu sosialisasi perpajakan. Jika WP diberikan pemahaman yang baik dan benar melalui sosialisasi, maka WP akan memiliki pengetahuan tentang pentingnya membayar pajak, sehingga kepatuhan wajib pajak akan meningkat. Hal ini diperkuat oleh penelitian yang dilakukan oleh Andriani, dkk, (2016) yang menyatakan bahwa sosialisasi perpajakan berpengaruh positif signifikan terhadap kepatuhan wajib pajak. Tetapi dalam penelitian lain yang dilakukan oleh Lianty, dkk (2018) menyatakan bahwa sosialisasi pajak tidak berpengaruh terhadap kepatuhan perpajakan. Faktor kedua yang diduga dapat meningkatkan kepatuhan yaitu pelayanan fiskus. Menurut Nurmantu (2005: 33), “Kualitas Petugas Pajak sangat menentukan efektivitas Undang-undang dan peraturan perpajakan. Adanya pelayanan yang 
baik dari petugas pajak, sistem perpajakan yang efisien dan efektif, serta penyuluhan-penyuluhan pajak yang memberikan motivasi kepada WP agar taat pajak, hal ini akan membuat WP memiliki keyakinan atau memilih perilaku taat pajak (Brata, dkk, 2017). Kondisi ini diperkuat oleh penelitian yang dilakukan oleh Maharani (2015) yang menyatakan bahwa pelayanan fiskus berpengaruh positiif signifikan terhadapkepatuhan WP. Sedangkan menurut Fitri Marcori (2018) menyatakan bahwa pelayanan fiskus tidak berpengaruh terhadap kepatuhan perpajakan

Selain dua faktor diatas, faktor yang diduga dapat meningkatkan kepatuhan yaitu pelaksanaan self assessment system. Dalam pelaksanaan self assessment system yang berlaku saat ini posisi WP sangat penting karena WP diwajibkan untuk melaksanakan pajaknya secara mandiri seperti perhitungan pajak, pembayaran pajak dan pelaporan pajak. Dengan demikian seorang WP dituntut untuk mengerti dan memahami tidak saja peraturan perpajakan, tetapi juga aspek administrasi serta prosedur perpajakan. Kesadaran masyarakat atau kepatuhan pajak seyogyanya menjadi hal utama dalam proses berjalannya pelaksanaan self assessment system, (Simanjuntak, dkk, 2012: 83-84). Self Assessment system berpengaruh terhadap kepatuhan WP di perkuat oleh penelitian Maharani (2015) tetapi bertolak belakang dengan penelitian Inggrid (2016) yang menyatakan self assessment system tidak berpengaruh terhadap kepatuhan WP.

Berdasarkan uraian di atas, maka dapat diajukan sebuah penelitian dengan judul mengenai “Kepatuhan Wajib Pajak UMKM Kota Semarang di Masa Pandemi Covid-19".

\section{Perumusan Masalah}

Perumusan masalah dalam penelitian ini adalah untuk mengetahui bagaimana pengaruh sosialisasi perpajakan, pelayanan fiskus dan pelaksanaan self assessment system terhadap kepatuhan Wajib Pajak UMKM di Kota Semarang di masa pandemi covid-19 baik secara parsial maupun simultan".

Tujuan Penelitian

Tujuan penelitian ini adalah untuk menganalisa bagaimana pengaruh sosialisasi perpajakan, pelayanan fiskus dan pelaksanaan self assessment system terhadap kepatuhan Wajib Pajak UMKM di Kota Semarang pada masa pandemi covid-19.

\section{LANDASAN TEORI}

\section{Teori Kepatuhan}

Theory of Planned Behavior yang mendasarkan asumsi bahwa manusia adalah makhluk yang rasional dan menggunakan informasi-informasi yang mungkin baginya, secara sistematis. Orang memikirkan Implikasi dari tindakan mereka sebelum mereka memutuskan untuk melakukan atau tidak melakukan perilakuperilaku tertentu (Astuti, dkk. 2016). Seperti halnya Frey dalam Simanjuntak, dkk, (2012: 101) mengemukakan bahwa salah satunya kunci faktor utama kepatuhan WP mengacu pada teori moral pajak (tax morale theory), memperkenalkan adanya motivasi intrinsik individu untuk bertindak, berdasarkan nilai-nilai yang di pengaruhi oleh norma-norma budaya yang diyakini seseorang mengapa membayar pajak. Beberapa faktor yang mempengaruhi teori moral pajak seperti: 
1. Persepsi adanya kejujuran.

2. Sikap membantu atau melayani dari aparat.

3. Kepercayaan terhadap instansi pemerintah.

4. Penghargaan atau rasa hormat dari aparat pajak (respect).

5. Sejumlah sifat-sifat individu lainnya.

\section{Definisi Pajak}

Pajak merupakan sumber penerimaan negara yang sangat penting dalam menopang pembiayaan pembangunan yang bersumber dari dalam negeri. Besar-kecilnya pajak akan menentukan kapasitas anggaran negara dalam membiayai pengeluaran negara, baik untuk pembiayaan pembangunan maupun untuk pembiayaan anggaran rutin. Oleh karena itu, guna mendapatkan penerimaan negara yang besar dari sektor pajak, maka dibutuhkan serangkaian upaya yang dapat meningkatkan, baik subjek maupun objek pajak yang ada (Simanjuntak, dkk. 2012: 9).

\section{Kepatuhan Wajib Pajak}

Nurmantu (2005: 148-149) berpendapat bahwa kepatuhan perpajakan didefinisikan sebagai suatu keadaan dimana WP memenuhi semua kewajiban perpajakan dan melaksanakan hak perpajakannya. Ada dua macam kepatuhan perpajakan yaitu kepatuhan formal dan kepatuhan material. Kepatuhan formal adalah suatu keadaan dimana WP memenuhi kewajiban perpajakan secara formal sesuai dengan ketentuan dalam undang-undang perpajakan. Sedangkan kepatuhan material adalah suatu keadaan dimana WP secara subtantif atau hakekat memenuhi ketentuan semua material perpajakan, yakni sesuai isi dan jiwa undangundang perpajakan.

\section{Sosialiasi Perpajakan}

Menurut Surat Edaran Dirjen Pajak No. SE-98/PJ/2011 tentang Pedoman Penyusunan Rencana Kerja dan Laporan Kegiatan Penyuluhan Perpajakan Unit Vertikal di Lingkungan Direktorat Jenderal Pajak, bahwa Sosialiasi atau Penyuluhan Perpajakan adalah suatu upaya dan proses memberikan informasi perpajakan untuk menghasilkan perubahan pengetahuan, keterampilan, dan sikap masyarakat, dunia usaha, aparat, serta lembaga pemerintah maupun non pemerintah agar terdorong untuk paham, sadar, peduli dan berkontribusi dalam melaksanakan kewajiban perpajakan.

\section{Pelayanan Fiskus}

Menurut Nasution (2006: 47) Petugas pajak (fiskus) adalah mereka yang harus menegakkan aturan permainan sistem perpajakan. Petugas pajak diharapkan simpatik, bersikap membantu, mudah dihubungi dan bekerja dengan jujur. Tanpa adanya perubahan kearah perilaku simpatik dan kejujuran dalam bertugas di kalangan petugas pajak, maka sulit untuk menumbuhkan kepatuhan masyarakat untuk membayar pajak. 


\section{Pelaksanaan Self Assessment System}

Menurut Farouq (2018: 157-158) berpendapat pelaksanaan self assessment system merupakan sistem pemungutan pajak yang memberikan kepercayaan kepada WP untuk menghitung atau memperhitungkan, membayar, dan melaporkan jumlah pajak terutang atas dirinya sendiri berdasarkan peraturan perundangundangan perpajakan.

\section{Usaha Mikro, Kecil dan Menengah (UMKM)}

Maharani (2015) mengemukakan Usaha Kecil dan Menengah (UKM) merupakan salah satu bagian terpenting dalam perekonomian kerakyatan di suatu wilayah maupun suatu Negara. Usaha kecil dan menengah sangat berperan dalam perekonomian Indonesia, sebagai contoh usaha kecil dan menengah sangat berperan penting pada saat terjadinya krisis moneter tahun 1998 dan dipandang sebagai suatu penyelamat dalam proses perekonomian Indonesia, mendorong laju pertumbuhan ekonomi maupun penyerapan tenaga kerja.

Rendahnya kepatuhan pajak dari para pelaku UMKM terkait dengan beberapa hal:

1. Pelaku UMKM didominasi oleh pelaku usaha rumah tangga. Berdasarkan pengamatan, kebanyakan pelaku UMKM dari kelompok ini kurang atau tidak peduli dengan masalah ketentuan yang berlaku. Termasuk

Tabel 1

Penelitian Terdahulu

\begin{tabular}{|c|c|c|c|c|c|}
\hline No & Judul & $\begin{array}{c}\text { Nama } \\
\text { Peneliti }\end{array}$ & Variabel & $\begin{array}{c}\text { Alat } \\
\text { Analisa }\end{array}$ & $\begin{array}{c}\text { Hasil } \\
\text { Penelitian }\end{array}$ \\
\hline 1. & $\begin{array}{l}\text { Pengaruh Self Assessment } \\
\text { System } \\
\text { dan Sistem Informasi } \\
\text { Perpajakan terhadap } \\
\text { Kepatuhan Wajib } \\
\text { Pajak (2017) }\end{array}$ & $\begin{array}{l}\text { Satyawati, } \\
\text { dkk }\end{array}$ & $\begin{array}{l}\text { Self assessment } \\
\text { system }\left(\mathrm{X}_{1}\right) \text {, } \\
\text { Sistem } \\
\text { Informasi }\left(\mathrm{X}_{2}\right) \text {, } \\
\text { Kepatuhan } \\
\text { wajib pajak }(\mathrm{Y})\end{array}$ & $\begin{array}{l}\text { Analisis } \\
\text { Regresi } \\
\text { Linier } \\
\text { Berganda }\end{array}$ & $\begin{array}{l}\text { Self assessment system dan } \\
\text { sistem informasi Perpajakan } \\
\text { berpengaruh positif terha- } \\
\text { dap kepatuhan wajib pajak }\end{array}$ \\
\hline 2. & $\begin{array}{l}\text { Pengaruh } \\
\text { Sosialisasi Pajak, } \\
\text { Pemahaman } \\
\text { Perpajakan dan } \\
\text { Tingkat Pendidikan } \\
\text { Terhadap } \\
\text { Kepatuhan Wajib Pajak } \\
\text { UMKM } \\
(2016) \\
\end{array}$ & $\begin{array}{l}\text { Andriani, } \\
\text { dkk }\end{array}$ & $\begin{array}{l}\text { Sosialisasi } \\
\text { Pajak }\left(\mathrm{X}_{1}\right) \text {, Pema- } \\
\text { haman Perpa- } \\
\text { jakan }\left(\mathrm{X}_{2}\right) \text {, Tingkat } \\
\text { Pendidikan } \\
\left(\mathrm{X}_{3}\right) \text {, Kepatuhan } \\
\text { Wajib Pajak } \\
(\mathrm{Y})\end{array}$ & $\begin{array}{l}\text { Analisis } \\
\text { Regresi } \\
\text { Linier } \\
\text { Berganda }\end{array}$ & $\begin{array}{l}\text { Sosialisasi Pajak dan Pema- } \\
\text { haman } \\
\text { Perpajakan berpengaruh } \\
\text { secara positif dan } \\
\text { Tingkat Pendidikan } \\
\text { berpengaruh negatif terha- } \\
\text { dap kepatuhan } \\
\text { Wajib Pajak UMKM } \\
\text { di Pasar Tanah Abang. }\end{array}$ \\
\hline 3. & $\begin{array}{l}\text { Pengaruh Self } \\
\text { Assessment } \\
\text { System, Tingkat Pendi- } \\
\text { dikan, dan Pelayanan } \\
\text { Fiskus terhadap Tingkat } \\
\text { Kepatuhan Wajib Pajak } \\
\text { UMKM di } \\
\text { Kota Pekanbaru (2015) }\end{array}$ & Maharani & $\begin{array}{l}\text { Self } \\
\text { Assessment } \\
\text { System }\left(\mathrm{X}_{1}\right) \text {, } \\
\text { Tingkat } \\
\text { pendidikan }\left(\mathrm{X}_{2}\right) \text {, } \\
\text { dan Pelayanan } \\
\text { fiskus }\left(\mathrm{X}_{3}\right) \text {, } \\
\text { Tingkat kepatu- } \\
\text { han } \\
\text { wajib pajak } \\
\text { UMKM }(\mathrm{Y})\end{array}$ & $\begin{array}{l}\text { Analisis } \\
\text { Regresi } \\
\text { Linier } \\
\text { Berganda }\end{array}$ & $\begin{array}{l}\text { Self assessment System ber- } \\
\text { pengaruh signifikan, tingkat } \\
\text { pendidikan berpengaruh } \\
\text { positif signifikan, dan } \\
\text { pelayanan fiskus berpen- } \\
\text { garuh signifikan terhadap } \\
\text { tingkat kepatuhan Wajib } \\
\text { Pajak UMKM di Pekanbaru. }\end{array}$ \\
\hline
\end{tabular}

Sumber : Review Penelitian Terdahulu, 2020

Kepatuhan Wajib Pajak Umkm Di Masa Pandemi Covid-19 Listiyowati, lin Indarti, Fitri Wijayanti \& Freddy Aldo Setiawan STIE Widya Manggala 
di dalamnya ketentuan perpajakan. Ketidakpedulian timbul, salah satunya, karena ketidakpahaman atas ketentuan-ketentuan yang berlaku.

2. Pelaku UMKM umumnya orang pribadi swa-usaha (self employment). Jenis pelaku usaha ini mempunyai karakteristik cenderung kurang patuh dibandingkan dengan karyawan, dimana atas penghasilan yang diperoleh telah dipotong pajak pada saat dibayarkan (witholding). Orang pribadi swa-usaha akan melaporkan seluruh penghasilan dari kegiatan usahanya dalam SPT. Namun, masih awamnya pelaku UMKM mengenai perpajakan menjadikan mereka masuk dalam kelompok tidak patuh.

3. Pelaku UMKM biasa bergerak di sektor informal, sehingga catatan yang ada atas pelaku UMKM dan transaksi yang dilakukannya relatif tidak ada. Hal ini menimbulkan kesulitan bagi administrasi pajak untuk mengawasi kepatuhan pajak pelaku UMKM.

\section{Model Penelitian}

Hipotesis dalam penelitian ini berkaitan dengan rumusan masalah, serta teori yang sudah dijabarkan, sehingga dapat membentuk model hipotesis sebagai berikut:

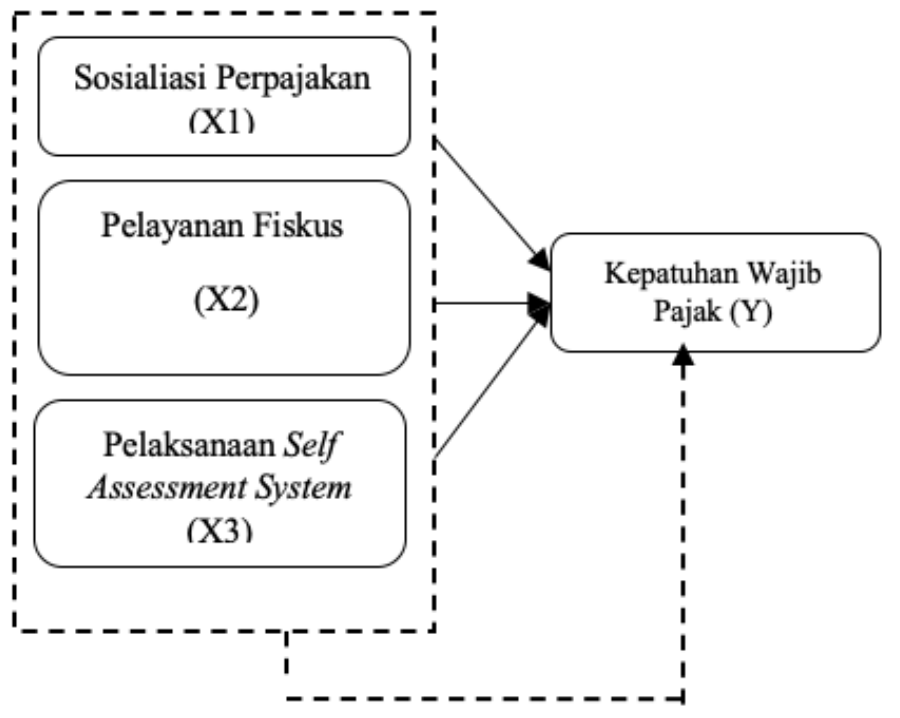

Gambar 1. Model Hipotesis

Sumber: Data diolah peneliti (2020)

\section{PENGEMBANGAN HIPOTESIS}

Normative beliefs sebagaimana dalam Theory of Planned Behavior (TPB) juga menjadi salah satu faktor penentu niat seseorang untuk berperilaku, dimana individu memiliki keyakinan atas motivasi atau dorongan dari orang lain (pihak luar). Seperti halnya sosialisasi perpajakan yang merupakan peranan penting dari 
pemerintah khususnya Dirjen Pajak untuk menjadi sarana informasi, pengetahuan, dan pemahaman pajak kepada Wajib Pajak. Sosialisasi perpajakan menjadi keyakinan Wajib Pajak (individu) untuk memotivasi agar menjadi perilaku taat pajak (Marjan, 2014) dalam Siahaan, dkk (2018). Penelitian ini diperkuat oleh penelitian yang dilakukan oleh Andriani, dkk (2016) yang menyebutkan bahwa sosialisasi pajak berpengaruh positif signifikan terhadap kepatuhan wajib pajak.

\section{$\mathbf{H}_{1}$ : Sosialisasi Perpajakan berpengaruh positif signifikan terhadap Kepatuhan Wajib Pajak}

Normative beliefs juga menjadi faktor penentu niat dari hasil pelayanan fiskus. Pelayanan fiskus yang berkualitas dan sesuai dengan aturan-aturan perpajakan menjadi dorongan yang memberikan keyakinan kepada Wajib Pajak untuk berperilaku patuh atau taat pajak karena Wajib Pajak merasa akan terbantu dan dimudahkan dalam menjalankan kewajiban perpajakannya (Marjan, 2014) dalam Siahaan, dkk (2018). Penelitian ini diperkuat oleh penelitian yang dilakukan oleh Maharani (2015) yang menyebutkan bahwa pelayanan pajak berpengaruh positif signifikan terhadap kepatuhan wajib pajak

\section{$\mathbf{H}_{2}$ : Pelayanan Fiskus berpengaruh positif signifikan terhadap Kepatuhan Wajib Pajak.}

Theory of Planned Behavior (TPB) merupakan prediksi perilaku yang baik karena diseimbangkan oleh niat untuk melaksanakan perilaku (Ajzen, 1991 dalam Andayani, 2016) dalam Siahaan, dkk (2018). Behavioral beliefs adalah salah satu faktor penentu niat seseorang untuk berperilaku, dimana individu memiliki keyakinan akan hasil dari suatu perilaku dan mengevaluasi perilaku yang baik dan kurang baik. Ketika Wajib Pajak memiliki keyakinan bahwa fungsi pajak sangat penting untuk pembangunan dan pembiayaan Negara, maka akan muncul pemikiran mengenai pentingnya Wajib Pajak sadar akan kewajiban perpajakannya (Marjan, 2014) dalam Siahaan, dkk (2018). Menurut Simanjuntak, dkk (2012: 83-84), Kesadaran masyarakat atau kepatuhan pajak seyogyanya menjadi hal utama dalam proses berjalannya pelaksanaan self assessment system. Penelitian ini diperkuat oleh penelitian yang dilakukan oleh Maharani (2015) yang menyebutkan bahwa pelaksanaan self assessment system berpengaruh positif signifikan terhadap kepatuhan wajib pajak

\section{$\mathbf{H}_{3}$ : Pelaksanaan Self Assessment System berpengaruh positif signifikan terhadap Kepatuhan Wajib Pajak. \\ $\mathrm{H}_{4}$ : Sosialisasi Perpajakan, Pelayanan Fiskus dan Pelaksanaan Self Assessment System berpengaruh signifikan terhadap Kepatuhan Wajib Pajak.}

\section{METODE PENELITIAN}

Penelitian ini menggunakan data primer yang berasal dari jawaban responden atau kuesioner yang diberikan sebelumnya. Peneliti akan memberikan sejumlah pertanyaan kepada wajib pajak yaitu pemilik usaha mikro kecil dan menengah di Kota Semarang dengan media kuesioner dan wajib pajak diminta untuk merespon, (Astuti, dkk, 2016). Populasi dalam penelitian ini adalah Wajib Pajak UMKM di Kota Semarang sebanyak 2.129 Wajib Pajak. Sampel dalam penelitian ini dihitung menggunakan rumus Slovin dan diperoleh 95 orang. Berdasarkan masing-masing skala usaha tersebut maka jumlah sampel pada usaha mikro sebanyak 
88 Wajib Pajak dan usaha kecil sebanyak 7 Wajib Pajak yang berada di Kota Semarang. Teknik pengambilan sampel dalam penelitian ini adalah teknik simple random sampling dengan menggunakan rumus slovin. Menurut Indriantoro dan Supomo (1999), simple random sampling adalah teknik pemilihan sampel secara acak sederhana berdasarkan strata.

\section{Definisi Operasional}

\section{Kepatuhan Wajib Pajak (Y)}

Kepatuhan wajib pajak adalah sebagai suatu keadaan dimana WP memenuhi semua kewajiban perpajakan dan melaksanakan hak perpajakannya.

Berdasarkan definisi tersebut, maka dimensi dari indikator kepatuhan wajib pajak adalah :

1. Wajib pajak memenuhi semua kewajiban perpajakan. Indikator dari dimensi berdasarkan Nurmantu (2005: 148-149) adalah :
a. Ketepatan memenuhi kewajiban perpajakan.
b. Ketepatan dan kejujuran dalam menyampaikan Surat Pemberitahuan Pajak.
c. Membayar pajak dengan tepat waktu.
d. Tidak memiliki tunggakan.
e. Bersedia memenuhi sanksi bila terjadi kesalahan.

2. Wajib pajak melaksanakan hak perpajakannya. Indikator dari dimensi berdasarkan Nurmantu (2005: 148-149) adalah :

a. Konsultasi dengan petugas pajak.

b. Tidak pernah dipidana dalam bidang perpajakan.

\section{Sosialiasi Perpajakan $\left(\mathbf{X}_{1}\right)$}

Sosialiasi atau Penyuluhan Perpajakan adalah suatu upaya dan proses memberikan informasi perpajakan untuk menghasilkan perubahan pengetahuan, keterampilan, dan sikap masyarakat, dunia usaha, aparat, serta lembaga pemerintah maupun non pemerintah agar terdorong untuk paham, sadar, peduli dan berkontribusi dalam melaksanakan kewajiban perpajakan. Berdasarkan definisi tersebut, maka dimensi dari indikator Sosialisasi Perpajakan adalah :

1. DJP memberikan informasi perpajakan kepada Wajib Pajak melalui kegiatan sosialisasi langsung untuk melaksanakan kewajiban perpajakan. Indikator dari dimensi berdasarkan Surat Edaran Dirjen Pajak No. SE-98/PJ/2011 adalah:
a. Penyuluhan pajak oleh fiskus pajak.
b. Diskusi dengan wajib pajak dan tokoh masyarakat.
c. Informasi langsung dari petugas ke wajib pajak.

2. DJP memberikan informasi perpajakan kepada Wajib Pajak melalui kegiatan sosialisasi tidak langsung untuk melaksanakan kewajiban perpajakan. Indikator dari dimensi berdasarkan Surat Edaran Dirjen Pajak No. SE-98/PJ/2011 adalah: 

a. Pemasangan billboard.
b. Website Ditjen Pajak.
c. Penyuluhan Melalui radio/televisi.

\section{Pelayanan Fiskus $\left(\mathrm{X}_{2}\right)$}

Petugas pajak (fiskus) adalah mereka yang harus menegakkan aturan permainan sistem perpajakan. Berdasarkan definisi tersebut, maka dimensi dari indikator pelayanan fiskus adalah:

1. Kualitas fiskus pajak dalam menegakkan aturan perpajakan. Indikator dari dimensi berdasarkan Nasution (2006: 47) adalah :

a. Pelayanan yang diberikan.

b. Kualitas Sumber Daya Manusia (SDM).

c. Pemahaman terhadap ketentuan perpajakan.

d. Sistem informasi perpajakan.

e. Kualitas lingkungan kantor pajak.

\section{Pelaksanaan Self Assessment System $\left(\mathrm{X}_{3}\right)$}

Pelaksanaan Self Assessment System adalah sebagai sistem pemungutan pajak yang memberikan kepercayaan kepada WP untuk menghitung atau memperhitungkan, membayar, dan melaporkan jumlah pajak terutang atas dirinya sendiri berdasarkan peraturan perundang-undangan perpajakan.

Berdasarkan definisi tersebut, maka dimensi dari indikator pelaksanaan self assessment system adalah:

1. Wajib pajak menghitung jumlah pajak terutang. Indikator dari dimensi berdasarkan Farouq (2018: 157158) adalah:

a. Menghitung dan atau memperhitungkan sendiri jumlah pajak yang terutang.

b. Menetapkan sendiri jumlah pajak yang terutang melalui pengisian SPT (Surat Pemberitahuan) dengan baik dan benar.

2. Wajib pajak membayar jumlah pajak terutang. Indikator dari dimensi berdasarkan Farouq (2018: 157-158) adalah:

a. Menyetorkan pajak tersebut ke bank persepsi/kantor pos.

3. Wajib pajak melaporkan jumlah pajak terutang. Indikator dari dimensi berdasarkan Farouq (2018: 157158) adalah:

a. Mendaftarkan diri di Kantor Pelayanan Pajak.

b. Melaporkan penyetoran tersebut kepada Direktur Jenderal Pajak (DJP).

\section{Metode Analisis Data}

Setelah data yang diperlukan telah terkumpul, selanjutnya dilakukan suatu analisis. Metode analisis data yang digunakan adalah statistik deskriptif dengan menggunakan teknik tabulasi frekuensi dan analisis linear berganda dengan bantuan program komputer SPSS. Sebelum dilakukan proses olah data maka peneliti 
melakukan uji kualitas data dengan menggunakan uji realibitas dan validitas serta Uji asumsi klasik dengan menggunakan uji normalitas, uji heterokedastisitas, dan uji multikolonieritas.

\section{HASIL DAN DISKUSI}

\section{Hasil Penelitian}

Uji Statistik Deskriptif menunjukkan bahwa jumlah responden berjumlah 78 responden dikarenakan dari total 95 responden, yang berhasil masuk dan lengkap berjumlah 78, dengan tingkat penyebaran data untuk X1 sebesar 4.043, X2 sebesar 6.076, X3 sebesar 4.012 dan Y berjumlah 3.257. Sedangkan untuk uji kualitas data yang terdiri dari uji validitas dan realibilitas menunjukkan bahwa nilai r-hitung $>$ dari $r$ tabel (0.2227), sehingga semua pertanyaan valid dan semua variabel mempunyai nilai lebih besar dari Cronbach's Alpha sebesar 0.7, sehingga semua semua variabel reliabel

Hasil uji asumsi klasik untuk uji normalitas data dengan menggunakan uji kolmogrov-smirnov menyebutkan nilai asymptotic significance (2-tailed) 0,388 yaitu lebih dari 5\%, sehingga dapat disimpulkan bahwa distribusi data adalah normal. Sedangkankan uji multikolonieritas nilai tolerance variabel bebas memiliki nilai lebih dari 10\%. Hasil perhitungan VIF juga menunjukkan hal yang sama, yaitu tidak ada variabel bebas yang memiliki nilai VIF lebih kecil dari 10. Jadi dapat disimpulkan bahwa tidak ada multikolinieritas antar variabel bebas dalam model regresi. Dan untuk uji heterokedastisitas dengan menggunakan gletjer diperoleh nilai hasil Sig untuk Sosialisasi Perpajakan $\left(\mathrm{X}_{1}\right)$ adalah 0,737, Sig untuk Pelayanan Fiskus $\left(\mathrm{X}_{2}\right)$ adalah 0,374 dan nilai Sig untuk Pelaksanaan Self Assessment System $\left(\mathrm{X}_{3}\right)$ adalah sebesar 0,081.

\section{Uji Regresi Linier Berganda}

Uji Partial

Tabel 2 Uji-t

\begin{tabular}{|c|c|c|c|c|c|}
\hline \multirow{2}{*}{ Model } & \multicolumn{2}{|c|}{ Unstandardized Coefficients } & \multirow{2}{*}{$\begin{array}{c}\begin{array}{c}\text { Standardized } \\
\text { Coefficients }\end{array} \\
\text { Beta } \\
\end{array}$} & \multirow{2}{*}{$\mathbf{t}$} & \multirow{2}{*}{ Sig. } \\
\hline & B & Std. Error & & & \\
\hline Constant & 17.332 & 2.813 & & 6.162 & 0.000 \\
\hline $\mathrm{X} 1$ & -0.109 & 0.118 & -0.135 & -0.925 & 0.358 \\
\hline $\mathrm{x} 2$ & 0.042 & 0.092 & 0.078 & 0.457 & 0.649 \\
\hline $\mathrm{X} 3$ & 0.413 & 0.115 & 0.509 & 3.608 & 0.001 \\
\hline
\end{tabular}

a.Dependent Variabel : Y

Sumber : Hasil olah data SPSS, 2020

Dari tabel diatas didapatkan persamaan sebagai berikut :

$$
\hat{Y}=17,322-0,109 X_{1}+0,042 X_{2}+0,413 x_{3}
$$

Berdasarkan hasil uji SPSS diperoleh $\mathrm{t}$ tabel $=1,993$; $\mathrm{t}$ hitung $=-0,925$. Berarti $-\mathrm{t}$ hitung $<-\mathrm{t}$ tabel dan nilai signifikan 0,358 > 0,05, maka Ho diterima. Dengan demikian dapat disimpulkan bahwa Sosialisasi Perpajakan 
$\left(X_{1}\right)$ tidak berpengaruh terhadap Kepatuhan Wajib Pajak ( $Y$ ). Hasil uji SPSS kedua diperoleh $t$ tabel = 1,993; $t$ hitung $=0,457$. Berarti t hitung $<\mathrm{t}$ tabel dan nilai signifikan 0,649 > 0,05, Maka Ho diterima. Dengan demikian dapat disimpulkan bahwa Pelayanan Fiskus $\left(\mathrm{X}_{2}\right)$ tidak berpengaruh terhadap Kepatuhan Wajib Pajak (Y). Hasil uji ketiga diperoleh $\mathrm{t}$ tabel $=1,993$; $\mathrm{t}$ hitung $=3,608$. Berarti $\mathrm{t}$ hitung $>\mathrm{t}$ tabel dan nilai signifikan 0,01< 0,05, maka Ho ditolak. Dengan demikian dapat disimpulkan bahwa Pelaksanaan Self Assessment System $\left(\mathrm{X}_{3}\right)$ berpengaruh positif signifikan terhadap Kepatuhan Wajib Pajak (Y).

Uji Serentak

Tabel 3 Uji-F

\begin{tabular}{lccccc}
\hline Model & $\begin{array}{c}\text { Sum of } \\
\text { Squares }\end{array}$ & df & Mean Square & F & Sig. \\
\hline Regression & 203.563 & 3 & 67.854 & 8.189 & $0.000^{b}$ \\
Residual & 613.155 & 74 & 8.286 & & \\
Total & 816.718 & 77 & & & \\
\hline
\end{tabular}

a. Dependent Variable: $Y$

b. Predictors: Constant), X1, X2, X3

Sumber : hasil Olah Data, 2020

Berdasarkan hasil perhitungan dan gambar tersebut, dimana $F$ tabel $=2,73$, $f$ hitung $=8,189$. Berarti $F$ hitung $>\mathrm{F}$ tabel, maka Ha diterima dan Ho ditolak. Dengan demikian dapat disimpulkan bahwa ada pengaruh secara simultan antara sosialisasi perpajakan $\left(X_{1}\right)$, pelayanan fiskus $\left(X_{2}\right)$ dan pelaksanaan self assessment system $\left(\mathrm{X}_{3}\right)$ terhadap variabel kepatuhan wajib pajak $(\mathrm{Y})$.

\section{Uji Koefisien Determinasi}

Tabel 4 Uji Koefisien Determinasi

\begin{tabular}{ccccc}
\hline Model & $\mathbf{R}$ & R Square & Adjusted R Square & $\begin{array}{c}\text { Std. Error of the } \\
\text { Estimate }\end{array}$ \\
\hline 1 & $0.499^{\mathrm{a}}$ & 0.249 & 0.219 & 2.879 \\
\hline
\end{tabular}

a.Predictors: (Constant),X1,X2,X3

b. Dependent Variable:Y

Sumber : Hasil Olah Data, 2020

Tabel 4 menunjukkan angka determinan (R) atau R-square yang digunakan untuk mengukur kemampuan variabel sosialisasi perpajakan $\left(X_{1}\right)$, pelayanan fiskus $\left(X_{2}\right)$ dan pelaksanaan self assessment system $\left(\mathrm{X}_{3}\right)$ dalam menjelaskan variabel kepatuhan wajib pajak $(\mathrm{Y})$. Hasil analisis regresi menunjukkan adjusted R-square sebesar 0,219 artinya 21,9\% variasi kepatuhan wajib pajak dapat dijelaskan oleh variasi dari tiga variabel independen yaitu sosialisasi perpajakan, pelayanan fiskus dan pelaksanaan self assessment system. Sedangkan selebihnya yaitu sebesar 78,1\% dipengaruhi oleh variabel-variabel lain diluar model. 


\section{Dikusi Hasil Penelitian}

1. Dari hasil pengujian hipotesis yang telah dilakukan menunjukkan nilai t hitung $=-0,925<$ dari nilai t tabel $=1,993$ (t hitung lebih kecil dari t tabel) dengan nilai signifikansi sebesar 0,358 Sedangkan a sebesar 5\% $(0,050)$ dengan $\mathrm{df}=74$ diperoleh $\mathrm{t}$ tabel $=1,993$. Berdasarkan hal tersebut maka dapat disimpulkan bahwa Hipotesis 1 ditolak artinya sosialisasi perpajakan tidak berpengaruh terhadap kepatuhan wajib pajak.

Hasil penelitian yang ada di UMKM Kota Semarang tidak sejalan dengan teori ini, dikarenakan sosialisasi tidak berpengaruh terhadap kepatuhan wajib pajak. Hal ini dikarenakan kurang optimalnya DJP dalam memberikan informasi perpajakan kepada WP melalui sosialisasi perpajakan terkait dengan peraturan perpajakan, Untuk itu perlu diadakannya penyuluhan pajak secara berkala, mengadakan berbagai acara yang berkaitan dengan peraturan pajak agar wajib pajak lebih memahami bagaimana melaksanakan kewajiban perpajakannya.

Hasil Penelitian ini sejalan dengan penelitian yang dilakukan oleh Astuti, dkk, (2016), menunjukkan sosialisasi perpajakan tidak berpengaruh signifikan terhadap tingkat kepatuhan wajib pajak dikarenakan sosisalisasi yang dilakukan dianggap belum maksimal. Hasil penelitian yang dilakukan oleh Siahaan, dkk (2018) menunjukkan bahwa sosialisasi perpajakan tidak berpengaruh terhadap kepatuhan wajib pajak. Sedangkan menurut penelitian Wardani, dkk, (2018) sosialisasi perpajakan berpengaruh signifikan terhadap kepatuhan wajib pajak.

2. Dari hasil pengujian hipotesis yang telah dilakukan menunjukkan nilai t hitung $=, 457<$ nilai $\mathrm{t}$ tabel $=$ 1,993 (t hitung lebih kecil dari t tabel) dengan nilai signifikansi sebesar 0,649 Sedangkan a sebesar 5\% $(0,050)$ dengan $\mathrm{df}=74$ diperoleh $\mathrm{t}$ tabel $=1,993$. Berdasarkan hal tersebut maka dapat disimpulkan bahwa Hipotesis 2 ditolak artinya pelayanan fiskus tidak berpengaruh terhadap kepatuhan wajib pajak. Hasil penelitian yang ada di UMKM Kota Semarang tidak sejalan dengan teori ini. Dalam penelitian ini pelayanan fiskus tidak berpengaruh terhadap kepatuhan wajib pajak, dikarenakan kurangnya pemahaman wajib pajak terhadap ketentuan perpajakan mengenai peraturan terbaru yang berlaku saat ini. Sehingga hal ini berdampak terhadap kurangnya pengetahuan wajib pajak yang berakibat turunnya tingkat kepatuhan wajib pajak. Untuk meningkatkan pelayanan fiskus kepada wajib pajak supaya mampu memberikan pengaruh terhadap kepatuhan wajib pajak maka perlu adanya pelayanan yang baik dari petugas pajak, sistem perpajakan yang efisien dan efektif, serta melaksanakan penyuluhan-penyuluhan pajak dalam memberikan info mengenai peraturan pajak terbaru yang memberikan motivasi kepada wajib pajak agar taat pajak, hal ini akan membuat wajib pajak memiliki keyakinan atau memilih perilaku taat pajak.

Hasil penelitian ini sejalan dengan penilitian yang dilakukan oleh Brata, dkk (2017), bahwa kualitas pelayanan tidak berpengaruh signifikan terhadap kepatuhan WP, hal ini terjadi karena kualitas pelayanan dari aparat pajak belum dapat memenuhi atau melebihi harapan WP. Hasil penelitian Siahaan, dkk (2018) juga menunjukkan bahwa pelayanan fiskus tidak berpengaruh terhadap kepatuhan wajib pajak.

Namun, hasil penelitian ini tidak sejalan dengan penelitian yang dilakukan oleh Astuti, dkk, (2016), hasil penelitian pelayanan fiskus menunjukkan bahwa pelayanan fiskus berpengaruh positif signifikan 
terhadap tingkat kepatuhan WP, hal ini dikarenakan bahwa petugas pajak telah memberikan pelayanan yang memuaskan kepada wajib pajak.

3. Dari hasil pengujian hipotesis yang telah dilakukan menunjukkan nilai t hitung $=3,608>$ nilai $t$ tabel $=1,993$ (t hitung lebih besar dari t tabel) dengan nilai signifikansi sebesar 0,001 Sedangkan a sebesar $5 \%(0,050)$ dengan $\mathrm{df}=74$ diperoleh $\mathrm{t}$ tabel $=1,993$. Berdasarkan hal tersebut maka dapat disimpulkan bahwa Hipotesis 3 diterima artinya pelaksanaan self assessment system terhadap kepatuhan wajib pajak berpengaruh positif signifikan.

Hasil penelitian ini sejalan dengan penelitian Maharani (2015), self assessment system berpengaruh signifikan terhadap tingkat kepatuhan WP UMKM di Kota Pekanbaru, hal ini menunjukkan bahwa ketika self assessment system tinggi, maka dapat meningkatkan tingkat kepatuhan WP UMKM, begitu juga sebaliknya. Hasil ini juga sejalan dengan penelitian yang dilakukan oleh Satyawati, dkk (2017) bahwa self assessment system berpengaruh positif terhadap kepatuhan wajib pajak.

Tetapi, hasil penelitian ini tidak sejalan dengan penelitian Astuti, dkk, (2016), pelaksanaan selfassessment system tidak berpengaruh signifikan terhadap kepatuhan WP. Hal ini dikarenakan pengetahuan dan pemahaman WP kos tentang pelaksanaan self assessment system masih kurang

4. Berdasarkan dari tabel nilai koefisien determinasi dengan menggunakan adjusted $R^{2}$ yaitu 0,219 artinya Sosialisasi Perpajakan $\left(\mathrm{X}_{1}\right)$, Pelayanan Fiskus $\left(\mathrm{X}_{2}\right)$, dan Pelaksanaan Self Assessment System $\left(\mathrm{X}_{3}\right)$ mempengaruhi Kepatuhan Wajib Pajak (Y) sebesar 21,90\%, sedangkan sisanya 78,10\% dipengaruhi oleh variabel lain diluar variabel yang diteliti. Variabel lainnya seperti kesadaran wajib pajak, kualitas pelayanan fiskus dan sanksi perpajakan dalam penelitian Jotopurnomo, dkk (2013). Dalam hal ini maka dapat disimpulkan bahwa hanya 21,90\% variasi yang terjadi pada variabel $Y$ dapat terjelaskan oleh variabel $X$ yang dimiliki, sedangkan sisanya dapat dijelaskan oleh variabel lain. Hal ini bisa saja terjadi dalam perhitungan statistik karena ada banyak hal yang dapat mempengaruhi mengapa nilai R Square menjadi kecil adalah variabel yang dikorelasikan memang kurang memiliki kaitan sehingga nilai korelasinya kecil. Dan berdasarkan hasil perhitungan SPSS, dimana nilai signifikansi 0,000; $\mathrm{F}$ tabel =2,73; $\mathrm{F}$ hitung = 8,189. Berarti F hitung > F tabel, maka Ha diterima dan Ho ditolak. Dengan demikian dapat disimpulkan bahwa ada pengaruh antara variabel Sosialisasi Perpajakan $\left(\mathrm{X}_{1}\right)$, Pelayanan Fiskus $\left(\mathrm{X}_{2}\right)$, dan Pelaksanaan Self Assessment System $\left(\mathrm{X}_{3}\right)$ terhadap variabel Kepatuhan Wajib Pajak $(\mathrm{Y})$ secara bersama-sama di Kota Semarang.

Penelitian ini sejalan dengan penelitian yang dilakukan oleh Andriani, dkk (2016) yang menyatakan bahwa Sosialisasi Pajak, Pemahaman Perpajakan, dan Tingkat Pendidikan secara bersama-sama berpengaruh signifikan terhadap Kepatuhan Wajib Pajak UMKM.

\section{KESIMPULAN, IMPLIKASI, DAN KETERBATASAN PENELITIAN}

\section{Kesimpulan}

1. Sosialisasi Perpajakan $\left(\mathrm{X}_{1}\right)$ tidak berpengaruh terhadap kepatuhan Wajib Pajak (Y) pada UMKM di Kota Semarang.

Kepatuhan Wajib Pajak Umkm Di Masa Pandemi Covid-19 
2. Pelayanan Fiskus $\left(\mathrm{X}_{2}\right)$ tidak berpengaruh terhadap kepatuhan Wajib Pajak (Y) pada UMKM di Kota Semarang.

3. Pelaksanaan Self Assessment System $\left(\mathrm{X}_{3}\right)$ berpengaruh positif signifikan terhadap kepatuhan Wajib Pajak (Y) pada UMKM di Kota Semarang.

4. Sosialisasi Perpajakan $\left(\mathrm{X}_{1}\right)$, Pelayanan Fiskus $\left(\mathrm{X}_{2}\right)$, Pelaksanaan Self Assessment System $\left(\mathrm{X}_{3}\right)$ secara bersamasama berpengaruh terhadap variabel kepatuhan Wajib Pajak (Y) pada UMKM di Kota Semarang.

\section{Dampak Penelitian}

Penelitian ini memberikan dampak positif bagi pengguna informasi yaitu UMKM itu sendiri dan pemerintah sebagai pemangku kebijakan. Dampak positif untuk UMKM adalah diberikannya stimulus oleh pemerintah dalam penurunan tingkat pembayaran pajak final sehingga mampu menurunkan tingkat beban pajak yang ditanggung oleh UMKM. Sedangkan untuk pemerintah dimana dalam penelitian ini diwakili oleh fiskus pajak mampu merangsang tingkat kepatuhan wajib pajak UMKM untuk membayar pajak. Sehingga ketika stimulus ini mampu meningkatkan tingkat kepatuhan WP maka akan mendorong meningkatnya tingkat penerimaan negara.

\section{Keterbatasan Penelitian}

Penelitian ini memberikan keterbatasan-keterbatasan yang wajib diperhatikan oleh peneliti-peneliti berikutnya diantaranya :

1. Populasi dalam penelitian ini dilakukan di KPP Semarang, sehingga bagi peneliti berikutnya bisa memperluas lokasi penelitian di KPP wilayah lain.

2. Dalam pembagian kuesioner tidak bisa dilakukan secara langsung dikarenakan kondisi pandemi Covid-19 ini. Tetapi penyebaran kuesioner dilakukan dengan menyebarkan kuesioner lewat email dan google form, sehingga hal ini berdampak terhadap UMKM yang kurang begitu menguasai tehnologi untuk melakukan pengisian kuesioner menjadi terhambat.

\section{Saran}

1. Saran yang berdasarkan hasil penelitian

Dirjen Jenderal Pajak diharapkan dapat lebih sering memberikan informasi perpajakan kepada Wajib Pajak mengenai peraturan pajak terbaru, agar wajib pajak dan calon wajib pajak dapat lebih memahami tentang ketentuan dan peraturan perpajakan yang terbaru. Sehingga dapat meningkatkan kepatuhan wajib pajak dalam memenuhi kewajibannya.

2. Saran yang berisi untuk Wajib Pajak UMKM di Kota Semarang

Para UMKM hendaknya dapat lebih meningkatkan kepatuhannya dalam memenuhi kewajiban pajaknya dengan meningkatkan Kesadaran Wajib Pajak terhadap kewajiban pajaknya dengan mendaftarkan sendiri sebagai Wajib Pajak untuk mendapatkan NPWP serta diharapkan dapat terus aktif untuk belajar perpajakan agar pemahaman mengenai peraturan perpajakan semakin meningkat demi terwujudnya 
pelaksanaan self assessment system $\left(\mathrm{X}_{3}\right)$ yang lebih baik. Dengan adanya self assessment system dapat meningkatkan sikap kesadaran masyarakat dalam memenuhi kewajiban perpajakannya sehingga kepatuhan wajib pajak menjadi meningkat.

3. Saran untuk penelitian selanjutnya

Untuk Penelitian selanjutnya diharapkan dapat memperluas lingkup penelitian yang berhubungan dengan UMKM dengan menambah objek penelitian yang lingkupnya tidak hanya UMKM di Kota Semarang tetapi UMKM di Jawa Tengah, serta dapat menambah variabel independen lainnya seperti kesadaran wajib pajak, kualitas pelayanan fiskus, dan sanksi perpajakan menurut (Jotopurnomo, dkk, 2013). 


\section{DAFTAR PUSTAKA}

Andriani, dkk. 2016. “Pengaruh Sosialisasi Pajak, Pemahaman Perpajakan, dan Tingkat Pendidikan terhadap Kepatuhan Wajib Pajak UMKM". Syariah Paper Accounting FEB UMS ISSN 2460-0784, 2016.

Astuti, dkk. 2016.“Pengaruh Sosialiasi Perpajakan, Pelayanan Fiskus dan Pelaksanaan Self Assessment System terhadap Kepatuhan Wajib Pajak atas Pajak Rumah Kos". Jurnal Nominal / Volume V Nomor 1 / Tahun 2016.

Brata, dkk. 2017. "Pengaruh Kesadaran Wajib Pajak, Pelayanan Fiskus, dan Sanksi Pajak terhadap Kepatuhan Wajib Pajak Orang Pribadi yang Melakukan Kegiatan Usaha dan Pekerjaan Bebas di Kota Samarinda". Forum Ekonomi ISSN Print: 1411-1713 ISSN Online: 2528-150X, Volume 19, No. 12017.

Direktorat Jenderal Pajak. 29 Desember 2011. Surat Edaran Nomor SE - 98/PJ/2011. Tentang Pedoman

Penyusunan Rencana Kerja dan Laporan Kegiatan Penyuluhan Perpajakan Unit Vertikal di Lingkungan Direktorat Jenderal Pajak.

Farouq, M. 2018. Hukum Pajak di Indonesia. Edisi Pertama. Perpustakaan Nasional: Katalog dalam Terbitan (KDT). Penerbit Kencana.

Fitri Marcori, 2018. “Pengaruh Kesadaran Wajib Pajak, Pelayanan Fiskus dan Sanksi Pajak Terhadap Kepatuhan Wajib Pajak Orang Pribadi yang Melakukan Usaha Kecil Menengah (Studi Empiris Pada KP2KP Kota Sungai Penuh". Fakultas Ekonomi Negeri Padang. Agustus 2018.

Indriantoro, dkk. 1999. Metodologi Penelitian Bisnis. BPFE, Yogyakarta.

Inggrid dan Swanto Sirait. 2016. “Pengaruh Pengetahuan Perpajakan dan Penerapan Self Assessment System Terhadap Kesadaran Wajib Pajak Serta Dampaknya Terhadap Kepatuhan Wajib Pajak Pada KPP Pratama Jakarta Penjaringan". Jurnal Media Akuntansi Perpajakan. ISSN 2355-9993 E-ISSN 2527-953X. Vol. 1, No. 2, Jul-Des 2016: 44-58

Jotopurnomo, dkk. 2013. "Pengaruh Kesadaran Wajib Pajak, Kualitas Pelayanan Fiskus, Sanksi

Perpajakan, Lingkungan Wajib Pajak Berada terhadap Kepatuhan Wajib Pajak Orang pribadi di

Surabaya". Tax \& Accounting Review.Vol.1, No.2

Lianty, dkk. 2017. “Pengetahuan Perpajakan, Sosialisasi Perpajakan dna Pelayanan Fiskus, Terhadap Kepatuhan Wajib Pajak". Jurnal Riset Akuntansi Kontemporer (JRAK), Volume 9 No. 2 Oktober 2017.

Maharani, Indah Sri. 2015. "Pengaruh Self Assessment System, Tingkat Pendidikan, dan Pelayanan

Fiskus terhadap Tingkat Kepatuhan Wajib Pajak UMKM di Kota Pekanbaru". Jurnal Jom Fekon Vol. 2 No. 2 Oktober 2015.

Nasution, Darmin. 2006. Dengan Pajak Kita Wujudkan Kemandirian Bangsa. Cetakan pertama. Jakarta: Penerbit Panitia Lomba Karya Tulis Perpajakan 2005. 
Nurmantu, Safri. 2005. Pengantar Perpajakan. Edisi 3. Jakarta: Penerbit Granit 2005.

Peraturan Walikota Semarang Nomor 12 Tahun 2008. Tentang Organisasi dan Tata Kerja Dinas Daerah Kota Semarang.

Satyawati, dkk. 2017. "Pengaruh Self Assessment System dan Sistem Informasi Perpajakan terhadap Kepatuhan Wajib Pajak". Jurnal JRAK, Volume 13, No 1 Februari 2017.

Siahaan, dkk. 2018. "Pengaruh Kesadaran Perpajakan, Sosialisasi Perpajakan, Pelayanan Fiskus, dan

Sanksi Perpajakan terhadap Kepatuhan Wajib Pajak Orang Pribadi". Jurnal Akuntansi, Vol.8, No 1 Februari 2018.

Simanjuntak, dkk. 2012. Dimensi Ekonomi Perpajakan Dalam Pembangunan Ekonomi. Jakarta:

Penerbit Raih asa Sukses (Penebar Swadaya Grup).

Wardani, dkk, 2018. "Pengaruh Sosialisasi Perpajakan terhadap Kepatuhan Wajib Pajak dengan

Pengetahuan Perpajakan sebagai Variabel Intervening". Jurnal Nominal / Volume VII Nomor 1 / Tahun 2018.

https://www.pajak.go.id/node/31403, diakses tanggal 30 April 2019.

https://www.republika.co.id, diakses tanggal 30 April 2019.

https://nasional.kontan.co.id/news/pasca-tarif-pajak-umkm-turun-jadi-05-jumlah-wajib-pajakmeningkat, diakses tanggal 30 April 2019.

https://www.kemenkeu.go.id, diakses tanggal 5 Mei 2019.

https://diskopumkm.semarangkota.go.id, diakses tanggal 22 Oktober 2019.

https://jateng.antaranews.com/berita/201856/setiap-tahun-tumbuh-2000-umkm-di-kotasemarang, diakses tanggal 23 Oktober 2019.

https://zonapasar.com/djp-jateng-i-genjot-penerimaan-pajak-umkm-5837, tgl 22 maret 2020. 